\section{Supporting the Writing Productivity of Biomedical Graduate Students: An Integrated, Structured Writing Intervention}

\author{
Susan A. Gardner, ${ }^{\dagger \ddagger}$ Lorena M. Salto, ${ }^{\dagger}$ Matt L. Riggs, ${ }^{\dagger 5}$ Carlos A. Casiano, ${ }^{\dagger}$ \\ and Marino De Leon ${ }^{\text {** }}$ \\ ${ }^{\dagger}$ Center for Health Disparities and Molecular Medicine, Loma Linda University, Loma Linda, CA \\ 92350; "Department of English, Walla Walla University, College Place, WA 99324; 'Department of \\ Psychology, California State University, San Bernardino, San Bernardino, CA 92407
}

\begin{abstract}
Writing is a critical skill for graduate students, but few studies in the literature describe how it is supported in the training of biomedical graduate students. The Initiative for Maximizing Student Development program at Loma Linda University aims to develop this important skill in its students through an integrated, structured writing intervention. Specifically, the program hired a writing specialist who taught writing seminars, facilitated writing and publishing workshops, and mentored students in one-on-one writing conferences. Doctoral students in the program, primarily underrepresented minority students with some not having English as a first language, all exhibited writing apprehension and blocking behaviors. The percentage of students graduating, publishing, and entering science careers, all of which require writing, is high. To yield insight into how this intervention worked, we conducted in-depth interviews of six of the earliest graduates, derived themes, analyzed data from pre- and post-assessments, and described their publication records. Participating students increased their writing confidence, adopted productive writing strategies, decreased writing anxiety and blocking behaviors, and published successfully.
\end{abstract}

\section{INTRODUCTION}

Writing is an essential element to complete a doctoral degree and to sustain a successful science career. At the graduate level, PhD students are faced with much more complex and demanding types of writing, including proposals, journal articles, dissertations, and grant/fellowship applications (Lavelle and Bushrow, 2007). They understand the role writing skills play in their identities and success as researchers and career scientists (Mullen, 2001). Graduate students are also taught that publishing in peer-reviewed journals plays a critical role in their careers. It is the "gold standard" to demonstrate scholarship and productivity (Cable et al., 2013). Thus, the importance of improving writing skills and learning to put together strong, cogent, and well-written scientific papers (Bredan and van Roy, 2006; Brand, 2008; Judge, 2013) cannot be stressed enough in graduate education, particularly in biomedical research, because "writing scientific articles is a daunting task for novice researchers" (Shah et al., 2009, p. 511). Kramer and Libhaber (2016) noted that "many academics agree writing for publication is one of the most difficult aspects of the process of research" (p. 115), yet many academics themselves simply do not have background or education in how to write for publication (Murray and Newton, 2008; Glew et al., 2014).

Although Rose and McClafferty (2001) addressed the need for graduate programs to provide writing instruction and support for students nearly 20 years ago, it has only been fairly recently that the call for such attention has been more insistent. Articles addressing the problem have noted there is an assumption that graduate students
Erin L. Dolan, Monitoring Editor

Submitted Dec 22, 2016; Revised Jun 8, 2018; Accepted Jun 12, 2018

CBE Life Sci Educ September 1, 2018 17:ar45 DOI:10.1187/cbe.16-12-0350

*Address correspondence to: Marino De Leon (mdeleonallu.edu).

() 2018 S. A. Gardner et al. CBE-Life Sciences Education (๑) 2018 The American Society for Cell Biology. This article is distributed by The American Society for Cell Biology under license from the author(s). It is available to the public under an Attribution-Noncommercial-Share Alike 3.0 Unported Creative Commons License (http://creativecommons.org/licenses/ by-nc-sa/3.0)

"ASCB®" and "The American Society for Cell Biology $\AA^{\prime \prime}$ are registered trademarks of The American Society for Cell Biology. 
come into their programs already knowing how to write, despite the fact that this type of writing is far more complex and unfamiliar than the writing students did before graduate school (Mullen, 2006; Maher et al., 2008; Plakhotnik and Rocco, 2012). There have also been increasing calls for writing instruction and support for those in graduate programs in the sciences and engineering (Simpson, 2012; Simpson et al., 2015; Glew et al., 2014). Some of the research in this area is coming from writing centers, writing program administrators, and writing across the curriculum initiatives. Some of these programs include stand-alone writing courses for graduate students, incorporating writing-intensive components into existing courses, or creating workshops or retreats specifically to help non-native or underprepared or unconfident graduate students for the academic writing required in the sciences (Florence and Yore, 2004; Simpson, 2012, 2013; Simpson et al., 2015; Glew et al., 2014; Badenhorst et al., 2015; Plakhotnik and Rocco, 2016). Specific instruction targeting graduate students in the sciences has been sparse until these more recent efforts.

Despite a lack of information, there is a definite need to support strong writing skills among all graduate students, because all writers face a variety of barriers when confronted with graduate-level writing tasks. These barriers include the following: 1) not understanding the writing process and lack of writing experience (Lavelle and Bushrow, 2007; Ludbrook, 2007; Kamler, 2008; Shah et al., 2009; Salas-Lopez et al., 2011); 2) finding the time to write (Grzybowski et al., 2003; Pugsley, 2009; Shah et al., 2009; Salas-Lopez et al., 2011); 3) lack of support and mentoring during writing (Mullen, 2001; Grzybowski et al., 2003; Ludbrook, 2007; Kamler, 2008; Maher et al., 2008; Shah et al., 2009; Plakhotnik and Rocco, 2012); 4) the difficulty of writing in a non-native language (Lee and Krashen, 2002; Watkins and Green, 2003; Wang and Bakken, 2004; Hu, 2005; Woodward-Kron, 2007; Cameron et al., 2009; Baron, 2012); and 5) fear of writing, termed "writing anxiety" or "writing apprehension" (Daly, 1978; Faigley et al., 1981; Huston, 1998; Onwuegbuzie, 1999; Onwuegbuzie and Collins, 2001; Mullen, 2006; Tomaska, 2007; Shah et al., 2009; Salas-Lopez et al., 2011; Kara, 2013).

In addition to these five barriers, another element that contributes to or prevents students from writing is their own self-efficacy beliefs (Plakhotnik and Rocco, 2016). Pajares (2003) pinpoints the importance of students' personal beliefs about their self-efficacy (first described by Bandura, 1986) as affecting their production of writing. In developing his theory, Bandura posited that self-efficacy beliefs derived from four sources: completing tasks successfully; observing and making comparisons to others' success in completing similar tasks; the "verbal messages and social persuasions," such as encouragement they receive from parents, teachers, and peers; and their own "emotional and physiological states such as anxiety and stress" when completing tasks (Usher and Pajares, 2008, p. 754). These four sources contribute to a view of being capable or not, and helping students develop positive self-efficacy beliefs can increase their confidence, motivate them to achieve, serve as a mediating force to reduce anxiety, and affect their success in academic tasks. Of significance, Salto et al. (2014) described how early interventions with high school and undergraduate students that increase academic and research self-efficacy can be impactful in the retention of underrepresented minority students in science, technology, engineering, and mathematics fields.

In addition to the absence of support for writers' self-efficacy, Kamler (2008) suggests "a lack of a framework or formal structures to sustain and support writing" (p. 283) is also responsible for minimal amounts of writing. Thus, including a framework or structure in graduate programs to reduce writing barriers and support upcoming academic scientists has the potential to increase their self-efficacy and enable them to produce publishable writing (Keen, 2007), complete their programs, and add to a more diverse scientific workforce (Valantine et al., 2016).

We have developed the Loma Linda University (LLU) Initiative for Maximizing Student Development (IMSD), established in 2001 and funded by the National Institutes of Health (NIH), to include such a framework. Our program's mission is to increase diversity among students graduating with $\mathrm{PhD}$ degrees in biomedical and behavioral sciences. As part of its mission, our program aims to create a well-trained cohort of diverse biomedical investigators and contribute to the elimination of health and educational disparities. To date, a total of 52 graduate students have participated in the LLU-NIH IMSD program; of those, $65 \%$ are Hispanic/Latino and $31 \%$ are African American.

From the program's inception, we aimed to support students' development of their writing skills and to reduce barriers to writing by going beyond the usual approach of a faculty principal investigator (PI) and the graduate student writing individually and together. Specifically, we hired a professor of English with a $\mathrm{PhD}$ in composition and rhetoric (the writing specialist and first author of this article [S.A.G.]) to implement a structured writing intervention that aimed to 1 ) provide basic writing instruction or review, as needed; 2) alleviate the writing anxiety of the graduate students; 3 ) serve as the "face" of writing in her roles as coach, mentor, and editor; and 4) establish a protected time and space where students came together with her to work on their writing. All of these emphases were designed to boost students' writing confidence, reduce their anxiety, build support for the writers, and help students produce scientific writing.

This article describes the implementation of this structured writing intervention. As part of ongoing LLU-NIH IMSD program assessment, we wanted to determine whether the structured writing intervention worked and matched the aims of increasing writing skills, reducing writing anxiety and blocking behaviors, and helping graduate students turn their research into published papers. We especially wanted to know whether elements of the structured writing intervention integrated into the biomedical research education of $\mathrm{PhD}$ students improved their writing confidence and led to production of scientific writing.

\section{METHODS}

\section{Participants and Context for the Study}

Similar to the sequential explanatory design described by Warfa (2016), this study describes a retrospective mixed-methods analysis using materials initially intended for program evaluation. A subgroup of six of $24 \mathrm{PhD}$ and $\mathrm{MD} / \mathrm{PhD}$ students who have graduated and were the earliest program participants were selected to participate in this study, because they were the first to complete all facets of the structured writing intervention 
with the writing specialist. They also had existing matched data collected from pre- and post-assessments and were available for on-site interviews before departing for postdoctoral positions in other parts of the country.

The six graduate students in the study, three men and three women, are all Hispanic and either second- or third-generation Mexican American or of Caribbean or South American heritage. Three of the six students are predominantly native-English speakers (NNES) but also speak and read Spanish, and the other three are NNES, with English as their second language. We gathered the data ourselves for evaluation purposes. However, we attempted to mitigate bias by making sure that at least two authors independently confirmed the observations of the components of the structured writing program in process, reviewed the transcribed interviews, and agreed on the themes derived from the interviews.

\section{Structured Writing Intervention}

We designed the writing intervention to include three main components (see Figure 1) aimed at creating a nonthreatening community of science writers who knew how writing is actually produced, what struggles writers face in clearly and effectively expressing their science, and what ground rules encourage supportive yet critical response. Particularly with NNES, a nonjudgmental, supportive response elicits more confidence, less fear, and, hence, more production than the traditional "slash and burn" model of critiquing papers (Kasper and Petrello, 1996). We used a writing group model (Gere, 1987; Grzybowski et al., 2003; Cuthbert and Spark, 2008; Maher et al., 2008; Aitchison, 2009; Shah et al., 2009; Plakhotnik and Rocco, 2012, 2016) to reduce writing anxiety and blocking behaviors (Rose, 1984) of all students, especially the NNES (Hu, 2005), with the goal of increasing students' writing confidence and productivity, succeeding at writing their dissertations, completing their program, and publishing their research.

\section{Three Components of the Writing Intervention}

Component 1. In their first year of graduate work, students attended a series of five required formal writing seminars presented by the writing specialist. These sessions focused on how writing really works across all disciplines, including science, the stages of the composing process, genres and formats of science writing, generating writing, precision in scientific language, grammar/usage, and ethics in science writing and publishing (see the Supplemental Material, Component 1). The hour-long seminars also served to introduce the writing specialist to the incoming graduate students.

Component 2. In their second year, graduate students joined the writing specialist in a weekly writing group. These writing and publishing workshops were not required, but students were encouraged to attend. The weekly sessions had a fixed location and protected time, which provided students a "soft" deadline for their work. Students brought printed copies of working drafts-grant proposals, scientific articles, abstracts, reviews, poster text, dissertation chapters, PowerPoint wording, and so on-for peer critique and editing/revision help. At the beginning of each writer's turn, the writing specialist asked several questions-What is this piece about? What genre is it? Who is the audience? What do you want from us?-and facilitated or guided the critiques from there (see the Supplemental Material, Component 2). Writers introduced what they were working on; identified what they needed or wanted help with; read the piece or sections of the piece aloud while the rest of the group followed along on the printed copies; and then listened to comments, questions, or suggestions from group members. Both the writer and the group members were free to ask questions about the clarity of the prose. Listeners made corrections, marked passages, and verbally challenged or asked questions about the science in the piece. Marked copies were returned to the writers to help with further revisions.

Component 3. When writers thought they needed more individualized writing help or final editing on a piece, the writing specialist implemented the third component: one-on-one conferences. These occurred both in face-to-face meetings and online as writers requested (see the Supplemental Material, Component 3). While the one-on-one conferences with the writing specialist were available to all of the students, the writing specialist emphasized participation in the writing and

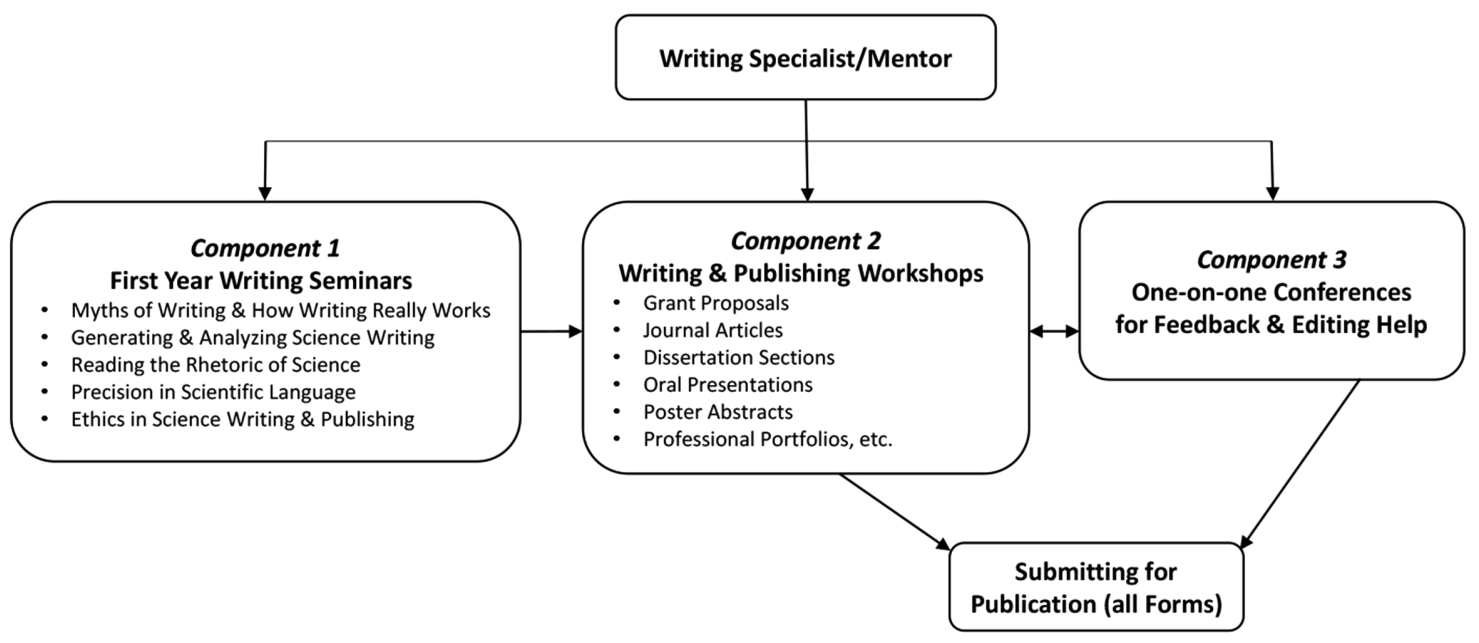

FIGURE 1. The LLU-NIH IMSD program structured writing intervention model. Component 1 is required of first-year LLU-NIH IMSD students. Component 2 is open to all LLU-NIH IMSD students after they have attended/completed first-year writing seminars. 
publishing workshops as the best way for students to receive feedback and improve their writing skills.

\section{Data Collection}

This retrospective study was approved by the Institutional Review Board of Loma Linda University. A waiver for informed consent was approved due to minimal risks to the research subjects. The names of students have been changed to protect their identities.

We administered two established survey instruments that measure writing apprehension and writing attitudes at the beginning (pre) and end (post) of the first two components of the writing intervention: the Daly-Miller Writing Apprehension Test (WAT; Daly and Miller, 1975a,b), adapted by Gungle and Taylor (1989) for use with NNES, and Rose's (1984) Writing Attitude Questionnaire (WAQ).

The Daly-Miller WAT measures writing apprehension by providing subscale scores for Evaluation Apprehension, Apprehension of Stress Experience, and Quality of Product Apprehension. The subscale score for Evaluation Apprehension measures the anxiety students feel when they have to have their writing judged. They often feel others do much better than they or get higher grades on their writing. They are nervous about their writing, especially showing their writing to others. The subscale score for Apprehension of Stress Experience measures the fearful feelings writers have even before doing any writing. This fear often causes them to block, procrastinate, or avoid writing at all costs. Organization of ideas seems to be especially difficult once the writer begins. The final subscale, Quality of Product Apprehension, addresses what causes writers to not want to write, viewing it as meaningless or a waste of time. Some writers have a hard time seeing real purpose or an audience for their writing and often do not take writing through the entire process of drafting, getting feedback, and then revising before submitting for evaluation (Daly and Miller, 1975a,b; DalyMiller Test, n.d.). For all scores, the higher the value, the lower the level of apprehension.

Rose's WAQ produces an omnibus scale score, along with five subscale scores that reflect attitudes believed to be important to writing productivity. These include 1) general attitude toward the process of writing, 2) belief that one can manage complex content, 3) ability to avoid lateness in completing writing tasks, 4) perceived ability to edit and revise, and 5) ability to avoid writer's block.

Along with collecting data through these two survey instruments, the writing specialist also conducted 45-minute interviews in 2009 with the six participants at the end of their doctoral program, using a set of open-ended descriptive questions (see the Supplemental Material, Interview Questions) to get their perspectives on what worked for them in the writing intervention. Additionally, she interviewed the LLU-NIH IMSD program director about his initial idea of including an integrated, structured writing intervention as part of the IMSD program. The interviews were transcribed verbatim for analysis.

To adequately describe the role of the writing specialist and to act as an external observer, the second author (L.M.S.) sat in on the first-year seminars and multiple writing and publishing workshops conducted by the specialist, keeping concise field notes to record observations. The second author (L.M.S.) also interviewed the writing specialist.
Finally, we examined the publishing records of the six participants as they finished their $\mathrm{PhD}$ programs and entered postdoctoral positions or went on to finish medical school. To determine a complete publication list, we performed a PubMed search for each student and indexed each publication by author and contribution, article title, year published, and complete author list. We considered a journal article to be a postgraduation publication if it was published any time after the student's graduation year. We also considered any other author contribution beyond first or second author. The total number of publications is current as of June 30, 2017, and includes postgraduation publications for each student.

\section{Data Analysis}

Survey and interview data were analyzed by two of the authors (S.A.G. and L.M.S.) who acted independently and collaboratively to examine the materials. The external program evaluator and third author (M.L.R.) analyzed the results of the survey instruments, which consisted of writing apprehension and writing attitudes (WAT and WAQ), and provided the statistical analysis discussed later. The first author (S.A.G.) has previous experience in ethnographic research and analyzed the text using content analysis to derive themes emerging from the repeated language of the participants (Spradley, 1979, 1980). The first and second authors (S.A.G. and L.M.S.) discussed the observations recorded in the field notes of the first-year seminars and writing and publishing workshops as well as notes from the interview of the writing specialist. In addition, they reviewed the transcripts of the interviews of the six participants and discussed the themes derived from the interview language to help mitigate bias.

\section{RESULTS}

Using both quantitative data from the survey instruments with follow-up qualitative data from analyzing the language of the interviews yielded a more complete understanding of changes taking place in the participants' views of writing, their attitudes toward writing, and their growing writing confidence. Two major themes emerged: 1) preprogram writing apprehension and 2) overcoming writing apprehension through the writing intervention.

\section{Preprogram Writing Apprehension}

Collectively, the students came into the program with higher levels of writing apprehension, which is evident in their survey results (Figure 2). Five of six participants also expressed writing apprehension during their interviews, noting that they entered the graduate program with unfavorable attitudes about writing as well as writing anxieties. Only Enrique, equally fluent in Spanish and English, did not view writing with fear, because he felt well prepared to write from his earlier education. Yesica, however, struggled with both spoken and written English and described her feelings when she joined the group of science writers in the writing and publishing workshop initially as

I hated it a lot at the beginning. Because I was so uncomfortable doing it, and I knew I [was] bad at it ... especially being critiqued and being on the spot, with ALL my witnesses right there. But at the same time I needed it. But it was hard. You don't want people telling you how bad you are... at something. But it had to happen. 


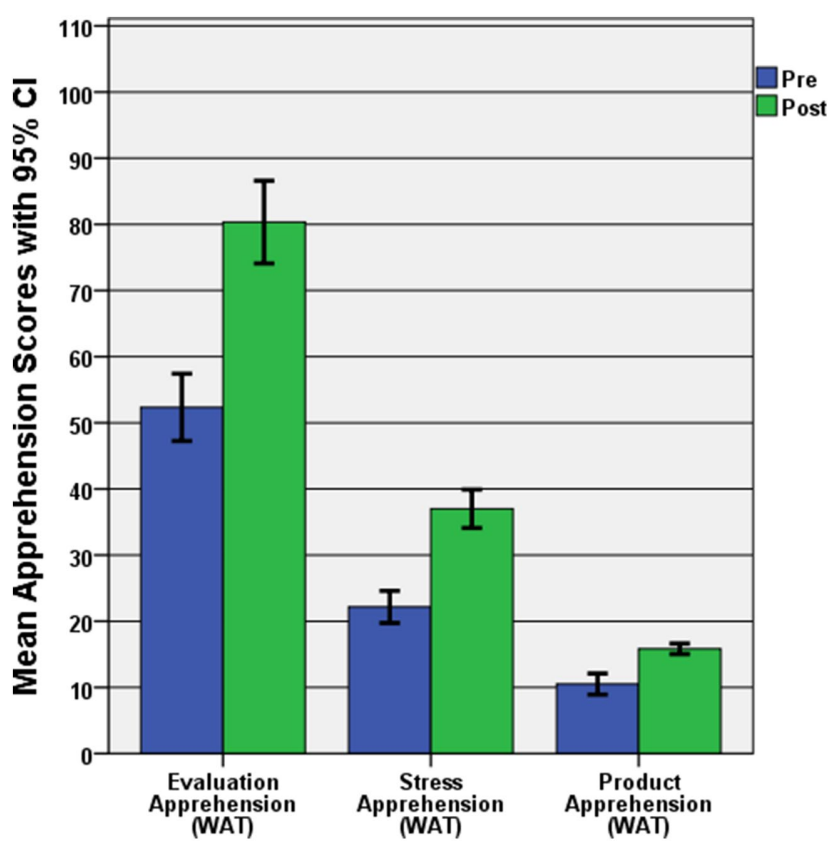

FIGURE 2. Pre/post Daly-Miller WAT results for the six LLU-NIH IMSD graduate students. The mean apprehension scores (with $95 \%$ confidence interval) are shown for the Evaluation Apprehension, Apprehension of Stress Experience, and Quality of Product Apprehension WAT subscales. Higher scores indicate lower apprehension.

Yesica's fear of speaking and then writing in English distracted her from her research. As she said, "I was not comfortable speaking in English. I was very self-conscious. I was more concerned with how I was pronouncing all those writing things than the actual data that I was presenting."

Daniela, one of the fluent English speakers born in the United States, concurred: "Writing was always a little scary for me just because I didn't think I was with everybody else in the way I expressed myself." Continuing her thought, she said, "The fear of writing ... was just blocking me from using the right words, the right grammar, and the punctuation. I was avoiding writing because of fear. I didn't want to do it."

Alicia, born in the United States and actually fluent in speaking and writing in both English and Spanish, also came into the program with a fear of writing, primarily based on experiences she had had in her undergraduate program at another university. She commented, "There was always that negative experience associated with writing. It was always something you had to do, and when you did it, it was always ripped apart in a very negative way ... No matter how hard you worked on it, it was never good enough." She talked extensively about "the psychological trauma" of always being critiqued in a negative way, which inhibited her in wanting to write. "I didn't feel like it [writing] was good because they didn't make us feel like it was worthy." Daniela also admitted this fear kept her doing only the minimum when asked to write. She said, "I didn't like writing. I did what I had to do with the writing and just to fulfill the basic requirements and that was it."

Getting frustrated, getting stuck, and worrying about being judged contributed to these graduate students' overall apprehension and attitudes about writing. They brought a lot of "writing baggage" with them. By the end of the program, however, their writing apprehension scores increased, indicating that, on average, their levels of apprehension decreased. For this particular set of students, the positive total WAT scale score change from pre- to postprogram was statistically significant $(t(5)=-21.55, p<0.001)$ and large in magnitude $(d=-5.89)$, and all three changes at the subscale level were also statistically significant $(t(5)=-18.96,-21.38$, and -17.18 , respectively; all $p$ values $<0.001$ ), with large $d$ change magnitudes of -5.19 , -5.85 , and -4.70 , respectively.

\section{Overcoming Writing Apprehension}

Students in this study overcame their writing apprehension and successfully produced writing. Collectively from the pre- to posttest scores on Rose's WAQ, the students reported more favorable attitudes toward writing (Figure 3), with significantly improved WAQ responses from pre- to postprogram $(t(5)=-7.01$, $p<0.001)$ that were large in magnitude $(d=-1.92)$. All subscale scores also moved in the desired direction, and four of the five (Complexity, Lateness, Editing, and Blocking) were statistically significant $(t(5)=-9.24,-6.24,-6.09$, and -5.45 , respectively; all $p$ values $<0.001)$. Effect sizes for all but General Attitude were large $(d=-2.53,-1.71,-1.67$, and -1.49 , respectively).

In their interviews, students also commented on their improved confidence in their writing and their writing production. As they overcome their initial fears, lack of background, and lack of English language skills and acquired more experience writing and being critiqued, their attitudes about writing and their blocking behaviors changed.

The students reported overcoming their initial fears and attributed this outcome to having more practice with writing,

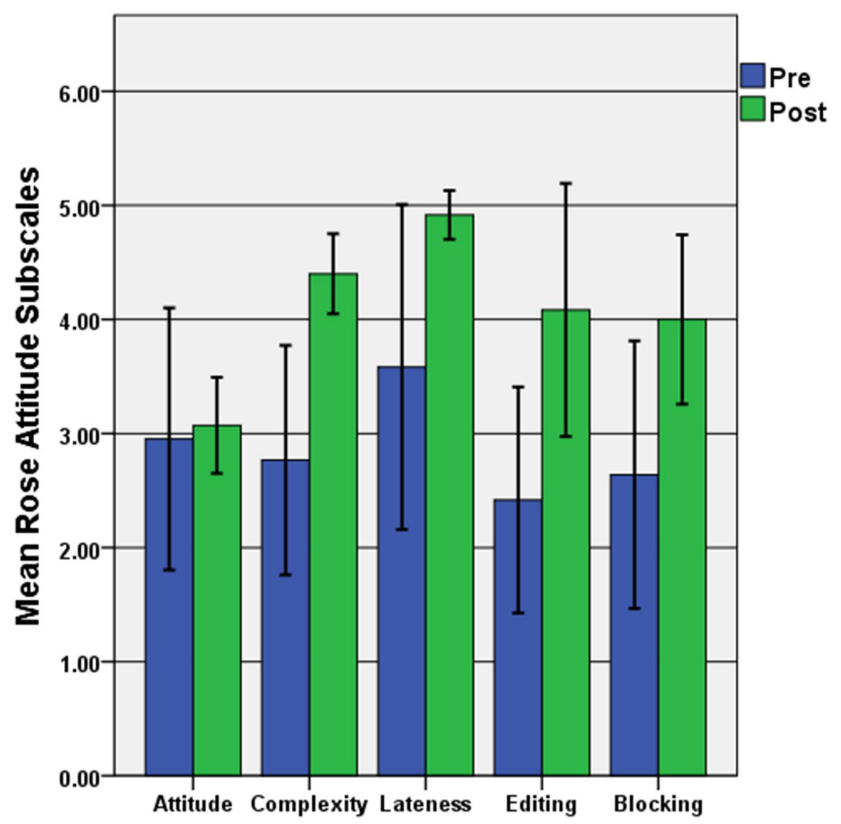

FIGURE 3. Pre/post Rose's WAQ scores for the six LLU-NIH IMSD graduate students. The mean scores are shown ( $\pm S D$ ) for the Attitude, Complexity, Lateness, Editing, and Blocking WAQ subscales. Higher values reflect higher levels of desirable beliefs and attitudes. 


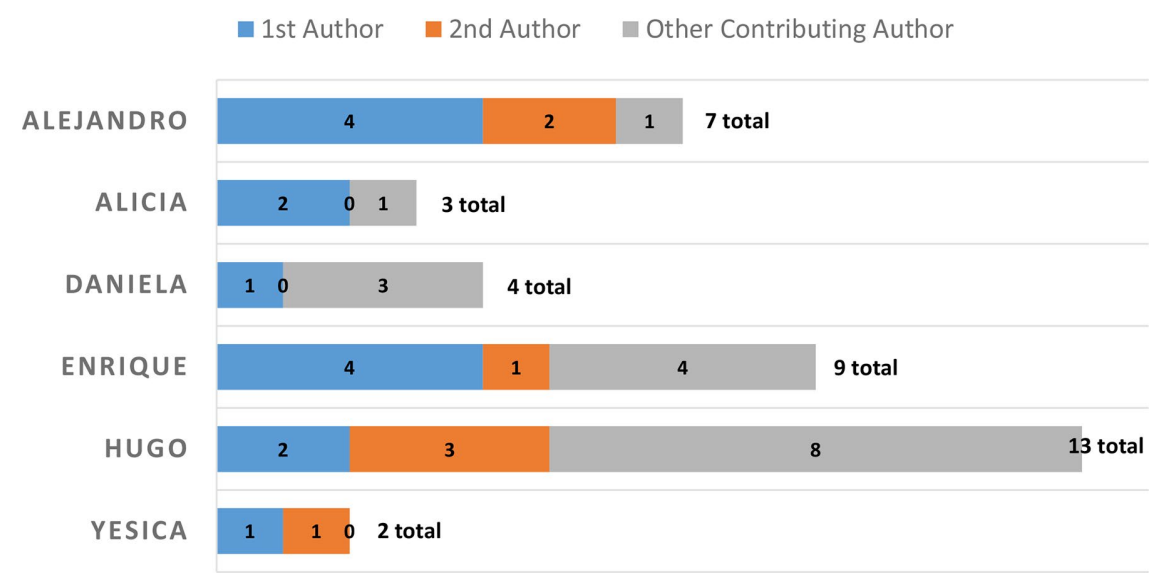

FIGURE 4. Peer-reviewed journal article publication record as of June 30,2017 , for the six LLU-NIH IMSD students.

revising, and being critiqued. For instance, Daniela commented, "It's not as difficult as before. I'm not afraid actually anymore just to write down what is on my mind or just do a paper."

Hugo also described the importance of more opportunities to write: "I think with practice that fear went away. I think the more time you try something, the easier it is for you to forget about that you couldn't do it when you can see that you are doing it!" Alicia concurred: "I can get my thoughts down on paper a lot quicker, and by doing that I think they're more organized, not just one complicated thought. Now I have a thought, I write it down and just let it flow basically. Keep writing." Alejandro learned the secret to writing and publishing; as he said, "It's revising, revising, revising. It's like practice makes perfect."

The writing and publishing workshops added to these gains in writing confidence and students' self-efficacy beliefs in their ability to produce writing. For example, Hugo commented, "When I started seeing that we all had the same problem, we were all struggling over the same little mistakes ... slowly it gave me confidence.... Now I'm not afraid of people critiquing it because we learned in the writing group that others had the same problem as well." Having more experience with all the stages of writing-drafting, being critiqued, and revising - and realizing other students were struggling, too, helped Hugo and others in the group be less afraid of writing and improved their self-efficacy beliefs about being competent writers.

With this newfound confidence, these young biomedical researchers saw the integral nature of writing to science. Alejandro succinctly stated, "If you are going to do research, you have to publish. You have to become a writer." Enrique backed up this position by saying, "The primary way to communicate is to publish your results, your presentations, so you've got to develop your writing skills along with your science skills. Writing is equally important because you could have awesome experience and data, but if you can't express them coherently and to the point, then they go nowhere."

Probably the most significant change in attitude and gain in writing confidence, again, came from Yesica. In two points of her interview, she made these comments:
I think hating writing is overrated. It's all a mental block that a lot of people have, and it takes time to get over that. You are expressing either your feelings or your ideas, you're sharing with other people. It's not impossible to become a good writer. It definitely takes a lot of time, dedication, and you have to be humble to the critiques and try to modify the things that are not necessarily right. Keep writing and researching and don't get stuck on one thing.

Finally, she noted that she believed she could write with "just a lot more practice, I know what I am doing, and that helps."

\section{Producing Writing}

All six graduate students succeeded in publishing a first-author, peer-reviewed journal article and earned their doctoral degrees. All continue to publish, with at least two and as many as 13 publications to date (Figure 4). The group, on average, published $2.33 \pm 1.36$ (mean \pm SD) first-author publications and $1.16 \pm$ 1.16 (mean \pm SD) second-author publications (two did not have any second-author publications). As a group, the students contributed to an average of $2.83 \pm 2.92$ (mean \pm SD) publications (one did not have any other contributing-author publications). The peer-reviewed publications of the students are presented as evidence that the students successfully produced writing and met the requirements of their program.

\section{Key Features of the Intervention}

Three themes emerged from the observations and interviews that provide some insight into how the intervention is working: the writing specialist's approach, interactions during the workshop, and peer modeling. Each is described separately here.

The Writing Specialist. The second author (L.M.S.) carefully observed the writing sessions, noticing that the writing specialist used a coaching-like teaching style and treated the students as high-level thinkers already capable of being good science writers. In her own words, the writing specialist firmly believed that the students "can't become science writers without the freedom to try and fail, try and fail but make progress, try and eventually succeed in clear expression, accurate science, and readable prose."

As Usher and Pajares (2008) noted, "the verbal and social persuasion that students receive from others" is another source of self-efficacy.... Encouragement from parents, teachers, and peers whom students trust can boost students' confidence in their academic capabilities" (p. 754). The graduate students commented on the lasting effect of the writing specialist, especially her encouragement to stop worrying about doing the writing and just write. As Hugo noted, "I had to start writing and I slowly got better at it through the help with the program ... The most useful thing you said once ... was 'just sit down and write. Forget about what you are writing, forget about the errors, forget about it if it doesn't make sense, just write.' And I did. And it works." 
Enrique, the most fluent writer, echoed Hugo by saying, "In the beginning I would kind of get stuck on a sentence or a paragraph and then move on. But then I learned, through your help, to just write the idea down and that has really improved my writing." Alicia echoed the same view: "I think the thing I learned most - that helped me the most—was just to get my thoughts on paper in a clear manner. I [didn't need to] dress it up and make it sound all fancy and complicated."

Yesica also emphasized this simple process of just writing. She commented, "I remember you said that sometimes it's better to just write and then later edit, gather your ideas ... and keep going with the flow of the writing." Alejandro reaffirmed this strategy as well: "What I've learned in your class is not to lay back. Start writing, write something. I've been doing that. Writing and then ideas will flow and you actually get something done."

Although this technique of just writing appears straightforward, students felt they had to overcome their perfectionism to be able to write. They reiterated the advice to just write liberated them from the perfectionism that was also blocking their productivity. For example, Daniela described how changing her process mitigated her perfectionism by saying,

[I now] just continue writing knowing that it doesn't have to be perfect the first time, that I can just continue writing and that I can leave it for a couple of hours, come back to it, or rewrite. I don't have to be stuck on one sentence to make it perfect to continue. It's okay to write without it being perfect. And you come back to it later on if you want to.

Even Alicia, who had been so stymied by her past experiences and her perfectionism, became more accepting of her early attempts at writing. As she said,

I know in the past that it would make my whole experience negative for me [because] I wanted the sentence to be perfect, I would just sit there... literally, for hours until the paragraph sounded just right....My experiences from the past were very negative, and now there is not a whole lot of emotion. Now when I write, it's like ok, I'm just writing my thoughts. There isn't this personal feeling invested in my writing.... Consequently, I'm writing more now and it's not as hard.

Workshop Interactions. The second author (L.M.S.) observed that the writing specialist modeled how colleagues ought to provide supportive and critical feedback to one another. After each student finished reading his or her piece aloud, the writing specialist first solicited reactions regarding the clarity of the work from the rest of the students. By deprioritizing her reaction, the writing specialist elevated the role of peer-to-peer feedback and prompted the students to think carefully about writing themselves, rather than implicitly telling them what they ought to be thinking by sharing her thinking first. She cued the students with the question, "What, in particular, is working well?"

The writing specialist added her suggestions on top of what the students said, answering technical questions as needed. Feedback on grammar and punctuation was mostly relegated to the mark-ups on copies of students' work so that the discussion could focus on the main ideas and the clarity of the writing.
Students also noted that the workshop interactions were critical to decreasing fear, overcoming perfectionism, and becoming more productive writers. Daniela referred to workshops as "additional backup support" because she knew she could share the writing with other scientists and receive good feedback. She commented,

The workshops we had were very helpful because we're together; it's not an intimidating setting. It's interactive and we are with other students that are doing similar writing, so it's very good feedback ... We just work together and that's one thing that I am more comfortable now with my writing, with actually having my papers evaluated. You can change the writing. We are all in this together. We all know what we are going through with research, with everything, so it's so supportive and it's not intimidating.

Enrique reiterated Daniela's point, noting the particularly supportive environment of the workshops: "We all learned from each other ... It's all constructive criticism in a really good environment that's nurturing." Hugo pointed out, "I want a backup person to look at this and say it makes sense or doesn't make sense ... The more people that do feedback, the better the paper."

Peer Modeling. An important component, according to Bandura, is "helping students build their efficacy beliefs through the vicarious experience of observing others" (Usher and Pajares, 2008, p. 753). The writing and publishing workshops served as the vehicle for allowing these six graduate students to carefully watch the social modeling of one another's progress as they brought pieces for discussion and feedback. The critiques were helpful, not harsh; the pieces did not have to be finished or perfect; the writers could learn what was clear and successful about their writing and what needed additional revision.

While some of the six regularly brought pieces for workshopping, others did not submit anything for quite a while, observing the process and watching their peers' reactions. Usher and Pajares (2008) noted that "students gauge their capabilities in relation to the performance of others (p. 753). In their research, they also found that watching others "who struggle through problems until they reach a successful end is more likely to boost the confidence of observers more than watching those who 'master' tasks easily" (p. 753). The modeling of their peers, or social modeling, seemed especially transformative in the boosting of writing self-efficacy for two of the graduate students, Yesica and Alicia.

When Yesica began the series of formal writing seminars, she came with trepidation, never volunteering anything except pleasant conversation. She attended but never offered to bring a piece for critique until she had watched her peers go through the workshopping process for many weeks. When she began to participate, she engaged more. As she said, "I saw other people doing it and it was not a bad experience. People would criticize, which was fine, and give suggestions but not mock or make me feel uncomfortable and absolutely bad about my writing."

Not only did she eventually allow others to critique her writing, which initially she described as "terrible flow with the sentences all fragmented," but she also began to gain enough writing confidence to critique others in their research and their 
drafts. As she said, "At the beginning it was mostly other people giving me their input of my project or writing skills. But then later it switched into me giving a little bit of ideas or my opinion on how things could be organized for their papers." She became a truly functioning member of the writing group through watching her peers model how to overcome writing challenges and finally jumping into peer critiques herself.

For Alicia, the workshops helped to provide social models and alleviate some of the physiological responses that Bandura noted could "undermine self-efficacy" (Usher and Pajares, 2008, p. 754). "What helped me get over this fear of presenting my work was because we got to do it in a friendly environment. People were critiquing it and giving their comments, but it wasn't negative. So it kind of helped take away all that trauma that I had ... That kind of changed the whole feeling of approaching writing, no longer associated with a very negative feeling. I think that helped a lot. You know, your peers critique it but in a friendly way."

Although changing Alicia's attitudes, reducing her fear of writing, and building her writing self-efficacy clearly happened during this mentored approach, the significance of it was when she went on for her postdoctoral appointment. Alicia noted, "My PI gives me a lot of feedback and responsibility and she trusts me with a lot of writing and stuff." After graduating from the LLUNIH IMSD program, Alicia was the one asked to do draft writing, and she communicated to the writing specialist (S.A.G.) that she ran a writing workshop on the drafts for more feedback and input by all the researchers on the project similar to the model used to help her overcome blocking behavior when writing.

\section{STUDY LIMITATIONS}

This study has several limitations. We present results from a small sample of the overall LLU-NIH IMSD student group. Nonetheless, the preprogram data support the need for writing support for graduate students. We present results only from participating students without any comparisons to students who did not participate in the program. Thus, our results may not be generalizable. The effectiveness of our program and programs with similar features would need to be determined using a different type of study design. Yet the post-program results are consistent with the idea that structured writing support can help apprehensive students overcome their apprehension and become productive writers by increasing their writing confidence.

\section{DISCUSSION}

Students in this study are similar to graduate students entering any PhD program. They entered it with unfavorable attitudes and fears about writing from their previous educational backgrounds, their native languages, and their views of themselves as successful and not so successful writers. These six students experienced the standard collaborative model of working with their PIs and other mentors on their research and writing, and they also worked intensively with the writing specialist in the LLU-NIH IMSD program's integrated, structured writing intervention.

The survey and interview results show that the intervention reduced students' writing apprehension and improved their confidence as writers. Through the intervention, the writing specialist was able to address the common barriers graduate students face when confronted with writing tasks, explain the writing process, provide a protected time and space for working on writing, mentor NNES writers in smoothing out their writing, reduce students' writing apprehension, and build their writing confidence. Participating students published successfully and finished their degrees. When told that not all $\mathrm{PhD}$ programs included the structured writing intervention and support similar to her LLU-NIH IMSD experience, Alicia expressed surprise: "I assumed it was just part-it just seemed like such a fundamental thing, you know. You need to be able to communicate your thoughts in writing, so where are you going to learn that? You are not going to learn it in graduate school, really, unless there is some sort of formal graduate trained person. It should be part of every program."

Alicia's comments provide insight into the support graduate students need for the writing and publishing they are expected to do, especially in the sciences. Unfortunately, writing programs (writing initiatives, writing centers), as Simpson (2012) has pointed out, focus efforts on and have funding primarily for undergraduates. Thus, one recommendation from this study, borne out by others calling for the same thing (Rose and McClafferty, 2001; Aitchison, 2009; Simpson, 2012, 2013; Simpson et al., 2015), is to create either a university-wide or a discipline-specific program to support graduate students in both writing and publishing. As the LLU-NIH IMSD director succinctly put it, "Without writing, there is no science. I can take a young scientist, teach him or her to do bench research, but if it doesn't get published, science does not move forward." The director viewed support for writing integrated into the IMSD program as essential for graduate students' success both in their programs and in their futures as scientists.

An important feature of integrating a structured writing intervention or providing writing support is the establishment of a set time and space, or protected time and safe environment, such as the writing and publishing workshops demonstrate. Graduate students may need to meet and go over drafts together and work on "translating research findings into scientific literature" (Kramer and Libhaber, 2016, p. 115), but these workshops provide even more. If facilitated by an outside writing specialist/coach or a supportive mentor from within an institution, the workshops can help provide the modeling of seeing peers write and get feedback. These workshop interactions can help mitigate negative emotions, the physiologic response, that solitary graduate student writers often experience. In addition, the facilitator can provide the social persuasion that encourages writers to view themselves and their writing in a more positive light. Writing alone can be a daunting, dull, and tedious task, and an integrated, structured writing intervention can be a place to help graduate students produce writing and make progress in completing their programs successfully.

\section{ACKNOWLEDGMENTS}

We thank all of the students and mentors of the LLU-NIH IMSD program who together and throughout the years have contributed to its success. We acknowledge and thank David Erghelegiu and Daniela Soto-Wilder for their administrative role and data management assistance. Finally, we are grateful for the support of the staff members at the Center for Health Disparities and Molecular Medicine. This study was funded by National Institute of General Medical Sciences award 5R25GM060507. 


\section{REFERENCES}

Aitchison, C. (2009). Writing groups for doctoral education. Studies in Higher Education, 34(8), 905-916.

Badenhorst, C., Moloney, C., Rosales, J., Dyer, J., \& Ru, L. (2015). Beyond deficit: Graduate student research-writing pedagogies. Technology Higher Education, 20(1), 1-11. https://doi.org/10.1080/13562517.2014 .945160

Bandura, A. (1986). Social foundations of thought and action: A social cognitive theory. Englewood Cliffs, NJ: Prentice Hall.

Baron, T. H. (2012). ABC's of writing medical papers in English. Korean Journal of Radiology, 13(S1), S1-S13.

Brand, R. A. (2008). Writing for clinical orthopaedics and related research Clinical Orthopaedics and Related Research, 466(1), 239-247.

Bredan, A. S., \& van Roy, F. (2006). Writing readable prose. EMBO Reports, 7(9), 846-849

Cable, C. T., Boyer, D., Colbert, C. Y., \& Boyer, E. W. (2013). The writing retreat: A high-yield clinical faculty development opportunity in academic writ ing. Journal of Graduate Medical Education, 5(2), 299-302. doi: https:// doi.org/10.4300/JGME-D-12-00159.1

Cameron, C., Deming, S. P., Notzon, B., \& Cantor, S. B. (2009). Scientific writing training for academic physicians of diverse language backgrounds Academic Medicine, 84(4), 505-510.

Cuthbert, D., \& Spark, C. (2008). Getting a GriP: Examining the outcomes of a pilot program to support graduate research students in writing for publication. Studies in Higher Education, 33(1), 77-88.

Daly, J. A. (1978). Writing apprehension and writing competency. Journal of Educational Research, 72(1), 10-14.

Daly, J. A., \& Miller, M. D. (1975a). The empirical development of an instrument to measure writing apprehension. Research in the Teaching of English, 9, 242-249

Daly, J. A., \& Miller, M. D. (1975b). Further studies on writing apprehension: SAT scores, success expectation, willingness to take advanced courses, and sex differences. Research in the Teaching of English, 9 $250-256$.

Daly-Miller test: How to calculate and read your score. (n.d.). Retrieved June 25, 2004, from www.csus.edu/indiv/s/stonerm/daly_miller_scoring.htm

Faigley, L., Daly, J. A., \& Witte, S. P. (1981). The role of writing apprehension in writing performance and competence. Journal of Educational Research, 75(1), 16-21.

Florence, M. K., \& Yore, L. D. (2004). Learning to write like a scientist: Coauthoring as an enculturation task. Journal of Research in Science Teaching, 41(6), 637-668

Gere, A. R. (1987). Writing groups: History, theory, and implications. Carbondale: Southern Illinois University Press.

Glew, R. H., Challa, A. K., \& Gopalan, V. (2014). Training in scientific manuscript writing. Current Science, 107(9), 1386-1392.

Grzybowski, S. C. W., Bates, J., Calam, B., Alred, J., Martin, R. E., Andrew, R., .. Berger, S. (2003). A physician peer support writing group. Family Medicine, 35(3), 195-201.

Gungle, B. W., \& Taylor, V. (1989). Writing apprehension and second language writers. In D. M. Johnson \& D. H. Roen (Eds.), Richness in writing: Empowering ESL students (pp. 235-248). New York: Longman.

Hu, G. (2005). Using peer review with Chinese ESL student writers. Language Teaching Research, 9(3), 321-342.

Huston, P. (1998). Resolving writer's block. Canadian Family Physician/Medecin de Famille Canadien, 44, 92-97.

Judge, B. (2013). The skill of writing. Journal of Medical Toxicology, 9, 4-5. doi: $10.1007 /$ s13181-012-0238-y

Kamler, B. (2008). Rethinking doctoral publication practices: Writing from and beyond the thesis. Studies in Higher Education, 33(3), 283-294.

Kara, S. (2013). Writing anxiety: A case study on students' reasons for anxiety in writing classes. Anadolu Journal of Education Sciences International, 3(1), 103-111.

Kasper, L. F., \& Petrello, B. A. (1996). Responding to ESL student writing: The value of a nonjudgmental approach. Community Review, 14, 5-12.

Keen, A. (2007). Writing for publication: Pressures, barriers and support strategies. Nursing Education Today, 27, 382-388.
Kramer, B., \& Libhaber, E. (2016). Writing for publication: Institutional support provides an enabling environment. BMC Medical Education, 16, 115. doi: 10.1186/s12909-016-0642-0

Lavelle, E., \& Bushrow, K. (2007). Writing approaches of graduate students Educational Psychologist, 27(6), 807-822.

Lee, S., \& Krashen, S. (2002). Predictors of success in writing in English as a foreign language: Reading, revision behavior, apprehension, and writing College Student Journal, 36(4), 532-543.

Ludbrook, J. (2007). Writing intelligible English prose for biomedical journals. Clinical and Experimental Pharmacology and Physiology, 34, 508-514.

Maher, D., Seaton, L., McMullen, C., Fitzgerald, T., Otsuji, E., \& Lee, A. (2008) "Becoming and being writers": The experiences of doctoral students in writing groups. Studies in Continuing Education, 30(3), 263-175

Mullen, C. A. (2001). The need for a curricular writing model for graduate students. Journal of Higher Education, 25(1), 117-126. doi: 10.1080/ 03098770020030551

Mullen, C. A. (2006). Best writing practices for graduate students: Reducing the discomfort of the blank screen. Kappa Delta Pi Record, 43(1), 30-35.

Murray, R., \& Newton, M. (2008). Facilitating writing for publication. Physiotherapy, 94, 29-34

Onwuegbuzie, A. J. (1999). Writing apprehension among graduate students: Its relationship to self-perceptions. Psychological Reports, 84, 1034-1039.

Onwuegbuzie, A. J., \& Collins, K. M. T. (2001). Writing apprehension and academic procrastination among graduate students. Perception of Motor Skills, 92, 560-562.

Pajares, F. (2003). Self-efficacy beliefs, motivation, and achievement in writing: A review of the literature. Reading and Writing Quarterly, 19, 139158.

Plakhotnik, M. S., \& Rocco, T. S. (2012). Implementing writing support circles with adult learners in a nonformal education setting: Priority, practice, and process. Adult Learning, 23(2), 76-81. doi: 10.1177/ 1045159512443507

Plakhotnik, M. S., \& Rocco, T. S. (2016). Increasing writing self-efficacy of adult learners: Different approaches, different results. Adult Learning, 27(4), 160-167. doi: 10.1177/1045159515611879

Pugsley, L. (2009). How to ... approach writing for publication in medical education. Education for Primary Care, 20, 122-124.

Rose, M. (1984). Writer's block: The cognitive dimension. Carbondale: Southern Illinois University Press.

Rose, M., \& McClafferty, K. A. (2001). A call for the teaching of writing in graduate education. Education Research, 30(2), 27-33.

Salas-Lopez, D., Deitrick, L., Mahady, E. T., Moser, K., Gertner, E. J., \& Sabino J. N. (2011). Getting published in an academic-community hospital: The success of writing groups. Journal of General Internal Medicine, 27(1) $113-116$

Salto, L. M., Riggs, M. L., De Leon, D., Casiano, C. A., \& De Leon, M. (2014) Underrepresented minority high school and college students repor STEM-pipeline sustaining gains after participating in the Loma Linda University Summer Health Disparities Research Program. PLOS ONE, 9(9), e108497.doi: 10.1371/journal.pone.0108497

Shah, J., Shah, A., \& Pietrobon, R. (2009). Scientific writing of novice researchers: What difficulties and encouragements do they encounter? Academic Medicine, 84, 511-516.

Simpson, S. (2012). The problem of graduate-level writing support: Building a cross-campus graduate writing initiative. WPA:Writing Program Administration , 36(1), 95-118

Simpson, S. (2013). Building for sustainability: Dissertation boot camp as a nexus of graduate writing support. Praxis: A Writing Center Journal, 10(2). Retrieved February 15, 2018, from https://praxis.uwc.utexas.edu/ index.php/praxis/article/view/129/html

Simpson, S., Clemens, R., Killingsworth, D. R., \& Ford, J. K. (2015). Creating a culture of communication: A graduate-level STEM communication fellows program at a science and engineering university. Across the Disc 12(3). Retrieved February 15, 2018, from https://wac.colostate.edu/atd/ graduate_wac/simpsonetal2015.cfm 
Spradley, J. P. (1979). The ethnographic interview. New York: Holt, Rinehart, \& Winston.

Spradley, J. P. (1980). Participant observation. New York: Holt, Rinehart, \& Winston Tomaska, L. (2007). Teaching how to prepare a manuscript by means of rewriting published scientific papers. Genetics, 175(1), 7-20.

Usher, E. L., \& Pajares, F. (2008). Sources of self-efficacy in school: Critical review of the literature and future directions. Review of Educational Research, 78(4), 751-796.

Valantine, H. A., Lund, P. K., \& Gammie, A. E. (2016). From the NIH: A systems approach to increasing the diversity of the biomedical research workforce. CBE-Life Sciences Education, 15(3), fe4
Wang, M., \& Bakken, L. L. (2004). An academic writing needs assessment of English-as-a-second-language clinical investigators. Journal of Continuing Education in the Health Professions, 24, 181-189.

Warfa, A-R. M. (2016). Mixed-methods design in biology education research: Approach and uses. CBE-Life Sciences Education, 15(4), rm5.

Watkins, S. E., \& Green, R. (2003). Speaking and writing proficiency of international graduate students in elective, mentoring environments. Journal of Engineering Education, 92(2), 147-154.

Woodward-Kron, R. (2007). Negotiating meanings and scaffolding learning: Writing support for non-English speaking background postgraduate students. Higher Education Research and Development, 26(3), 253-268. 